\title{
The sights and sounds of the multilingual city
}

\section{Lorna Carson}

Cities have the capability of providing something for everybody, only because, and only when, they are created by everybody.

— Jane Jacobs, The Death and Life of Great American Cities.

[Insert Figure 2.1: Bench beside Dublin Bay]

Within a short walk of my home beside Dublin Bay, I regularly walk past two park benches on the footpath which seem to be pointing the wrong way. They face away from the road (unlike benches located near bus stops), and instead they are angled towards a stone wall. The beach ends about a hundred metres before the benches. When I stop to investigate, I see the top of the wall, some trees, bushes and a grassy area on the other side of the wall, and, on the horizon, an industrial area with a power station, water treatment plant and so forth. What a peculiar site for park benches! Why are they there, and what are people supposed to look at when they sit down?

To answer these questions, a passer-by needs to know some of the history of Dublin Bay and its reclaimed land. Previously, the wall that these park benches face was the sea wall, and on the other side was the beach. The beach that now ends several hundred metres away continued on, and passers-by would have once enjoyed a sea-view before the land was reclaimed. What caught my attention when I first saw these benches was the notion of indexing — we assume that park benches are deliberately placed in locations which point us towards a view, and indeed in many parts of national parks and other areas of beauty, we often find a welcome bench for a picnic or a just a rest which also orients visitors towards features in the landscape. In the study of linguistic landscapes, the idea of indexicality (or pointing us towards something) helps us understand something about the presence and vitality of languages in a city and in turn their speech communities.

Taking another example, the Dutch city of Utrecht is often described as a multilingual hotspot. However, despite the many visible languages in the city, there 
are not very many instances of East Asian languages. One sign stands out because of its use of Japanese. The information sign about a museum, the dick bruna huis, uses Dutch, English and Japanese to inform readers about ticket purchases. The uses of Dutch and English are not surprising. But why Japanese here, and not elsewhere in Utrecht? Why not French or Spanish for instance, like the tourist menus in the city? The Japanese language is almost invisible in the rest of the city.

To understand why Japanese is used here, we must understand something about the museum itself. This permanent exhibition celebrates the work of Dick Bruna, creator of the Miffy series of children's books, and the choice of including Japanese language in the sign provides a clue as to the popularity of the central character, a cartoon rabbit, in Japan. Miffy is such an important part of Japanese popular culture that many people assume she is a Japanese creation, like Hello Kitty. Indeed, the museum describes how some Japanese couples choose to organise their honeymoon around a visit to the dick bruna huis, and Utrecht is mentioned as 'the city of Miffy' in all Japanese tour guides. In other words, we learn that the choice of Japanese in this part of the city is a deliberate choice. Yet it stands out as there are very few other instances of Japanese elsewhere. Knowledge of Japanese popular culture explains the popularity of Miffy and the reasons for this sign. Building on this knowledge and the fact that many Japanese tourists are present suggests that more signs could usefully display information in Japanese to help such tourists and perhaps attract more.

\section{[Insert Figure 2.2: dick bruna huis in Utrecht]}

It is also important to note early in this chapter that some examples of multilingualism can be incidental rather than indexical, meaning that some instances of the multilingualism we see and hear around us may be less salient than others. In Osijek, trams imported from Germany still display German language signage. In Varna, the instructions on vending machines often remain in the original language of their country of origin. Sometimes a translation in Bulgarian is provided, but not always. A medical technician interviewed by the authors of the Strasbourg City Report explained that most of instruction manuals of medical devices are in English. The same respondent described a similar situation when using computer software. These appearances of German, Bulgarian and English say something about trade and 
globalisation, and how employees or even customers must sometimes cope with other language varieties in their sphere, but they are not necessarily indexical of the key issues experienced in Osijek, Varna or Strasbourg. The approach employed by the LUCIDE research sets out to capture some of the most relevant features of a city's linguistic landscape, the instances that help us understand how multilingual citizen communities most typically live and work and which point to the vitality of the languages in a city environment.

\section{Investigating multilingual cityscapes}

\section{[Insert Figure 2.3: Dublin shop front]}

Cities are sites of intensive language contact. Our daily activities are surrounded by visual messages in a variety of scripts and registers. Sometimes a place can be famous for the signs that appear in the cityscape - think of Times Square in New York, the tourist trade in reproductions of Parisian street and café signs, Chinatown in London. But it is not simply about the signs or the languages used. Our cities are 'the interweaving of human patterns' (Raskin, in Jacobs, 1961: 229): 'They are full of people doing different things, with different reasons and different ends in view, and the architecture reflects and expresses this difference - which is one of content rather than form alone.' The city's streets provide its main visual focus for citizens and visitors. Jacobs (1961: 378) describes the 'detail and activity' therein:

[Streets] make a visual announcement (very useful to us for understanding the order of cities) that this is an intense life and that into its composition go many different things. They make this announcement to us not only because we may see considerable activities itself, but because we see, in different types of buildings, signs, store fronts or other enterprises or institutions, and so on, the inanimate evidences of activity and diversity.

The streets of the LUCIDE cities were the focus of the network's primary and secondary data collection. As outlined in the Introduction, the theme of urban spaces, or the 'cityscape', was one of five key spheres of city life identified by the research team. By 'urban spaces' we mean all publicly visible and audible aspects of a city, or what Scollon and Scollon (2003) describe as discourses in place. This includes the analysis of language in public signage, advertising, official and unofficial street art, instructions and announcements. These visual and audible aspects of multilingualism 
are the external markers of a city's many speech communities. Very often, however, citizens may be blind to the languages which appear in the cityscape, and unaware of the decision-making behind them. This is not just a case of monolingual bias, but also a case of efficiency, and only selecting or decoding that which is necessary within a language environment.

For instance, whilst a walk around the central business district or most residential neighbourhoods of any European city would allow us to hear a wide variety of languages (especially if we are able to distinguish between them), we may not see any written examples of these languages in what is described as the linguistic landscape of a city. In fact, some of the languages present in a city may be entirely invisible, or appear only in unofficial signs. And what about the predominance of some languages, especially English, in the marketplace or in tourism? What is going on when we see multiple languages in a city street? How do these connect with daily life? Are they meaningful at the level of society or politics? Are they indexing different types of relationships between communities? Who decides to place such signs? What language choices do these decision-makers face? As Bogatto and Hélot explain,

the production and display of such messages are in no way trivial or insignificant. On the contrary, they are used to mark a given space even if only symbolically, to mark oneself out as different from others or to express one's identity in various ways and through different processes. (2010:17)

Whilst interest in how languages and scripts (and which languages and scripts) feature in city life has existed arguably since the Rosetta Stone, the academic study of manifestations of language use in the cityscape has gathered considerable momentum in recent years, especially in areas where language choice is politically and socially contested. Rosenbaum et al. (1977) examined signage in Jerusalem; Tulp (1978) looked at the distribution of commercial billboards in French and Dutch in Brussels; Monnier (1989) explored compliance with the law in French language use in shop fronts in Montreal. The term 'linguistic landscape' was coined by Landry and Bourhis (1997: 25):

The language of public road signs, advertising billboards, street names, place names, commercial shop signs, and public signs on government buildings 
combines to form the linguistic landscape of a given territory, region, or urban agglomeration.

This field of study employs photography and mapping techniques to capture and analyse the languages that surround us. It draws on disciplines such as geography and urbanism, sociology and political science, to understand what is going on within and behind the written discourse in the public (and sometimes private) spaces of contemporary society. The 'mushrooming' of multilingualism in cities is not something incidental or adjacent to everyday life, like a decorative Chinese arch when entering Chinatown, but is meaningful, in the way that the languages we see in signs and hear around us in fact point to the presence of vitality in speech communities. The visible evidence of multilingualism in cities - on noticeboards, billboards, electronic screens, instruction leaflets, in graffiti and in public announcements - form part of a dialogue between those who place such signs and those who read the signs. Below, we explore how such visual and audible evidence points to varying degrees of vitality in the languages represented.

\section{A snapshot of LUCIDE cityscapes}

In the cityscapes described in the LUCIDE City Reports, the private and economic spheres of city life tend to be sites of multilingual language use whilst signs that appear in the public sphere tend towards either monolingualism or bilingualism as set out by law. For example, the authors of the Montreal City Report describe it as 'an officially unilingual city in an officially unilingual province in an officially bilingual country', but go on to point out that it is in fact a highly multilingual city. Commercial properties in the city are subject to the Charter of the French Language, explored in more detail below, but increasingly languages such as Spanish and Arabic are also visible in the city. The Saint-Michel area is home to a Maghreb community, with many stores, coffee shops and restaurants, and Spanish is visible in the streets of the Rosemont-Petite-Patrie area.

All of the LUCIDE City Reports refer to the vitality of multilingualism in central districts as well as in specific neighbourhoods, some of which are designated as a 'Chinatown', 'Little Italy' or 'Little Greece', as explored in the next chapter. The visual character of these named areas grows from waves of immigration in neighbourhoods where immigrants first settled. It is interesting to compare cities with 
established patterns of immigration and cities with more recent experiences of immigration. The City Reports from Melbourne and Dublin point to old and new versions of specifically named ethnolinguistic areas. In Australia, gold was discovered in the Victorian goldfield in the 1850s. Thousands of Chinese immigrants emigrated to Melbourne, and the impact of the Chinese remains evident throughout Melbourne. This is especially the case around the area that is described as Melbourne's 'Chinatown', Little Bourke Street where shoppers pass under a traditional Chinese arch. The author of the Melbourne City Report describes it as a 'a lively and colourful precinct filled with shops and restaurants', which is an established part of Melbourne's cityscape.

On the other hand, whilst the city of Dublin has resisted creating a designated district, the arrival of many Chinese entrepreneurs in the north inner city has created a de facto Chinatown. Mottiar and Walsh (2012) provide an insight into one street in this part of the city, Parnell Street East. This deprived inner city district of historical significance was known briefly as 'Little Africa' before transforming over the last ten years into an area with many Asian entrepreneurs. The authors describe the aspirations of local business owners to erect an arch marking this status, as in other international cities with a 'Chinatown'. Their paper points to 'the tension that exists between whether areas should be encouraged and supported to develop as specific monocultural area such as a Chinatown, or in a more multicultural form encompassing other immigrant and local groups who operate and use such urban space' (2012: 29). A group of restaurants in this district have created a website which promotes Dublin's Chinatown (including Japanese and Korean restaurants), despite the city's reluctance to endorse the name.

Melbourne's Italian immigrants arrived between the 1920s and 1950s, and many settled in the neighbourhood of Carlton. Whilst the percentage of Italian residents has declined over the years, Lygon Street, where the city's famous café culture was born, remains at the heart of Melbourne's 'Little Italy'. In Dublin, it is evident that the City Council has sanctioned the naming of the city's new 'Italian Quarter' through mentions in official documentation such as its Public Realm Strategy (although 'Chinatown' is conspicuous in its absence). This newly designed district was the result of urban planning in coffee shops and restaurants rather than representing the site of Ireland's original Italian population. One Dublin interviewee touched on the peculiarities of newly 'branded' areas when asked about language 
visibility. She noted 'a lack of signage and knowledge of the Italian quarter' among locals, despite its being described as such in tourist guides to Dublin. Italian migrants came to Ireland between the late 18th and early 20th centuries, finding work in the stucco, mosaic and terrazzo industry of Dublin's grand building projects (Reynolds, 1993; Dietz, 2011). Later, other Italian immigrants found work in catering and hospitality; many Irish-Italian families are descended from a single chain migration, which commenced in 1912 in the region of Lucca, and they still continue the fish and chip trade in Dublin (De Tona, 2006; King and Reynolds, 1994). However, these well-established fish and chip shops (named, for instance, after the Borza, Macari, Cafolla and Apriles families) are not located in the city's 'Italian Quarter'.

We will return to the discussion of specifically designated areas and fears of ghettoization in Chapter Three, but it is worth drawing attention to the question of branding, authenticity and the gradual shift of newly arrived immigrants from inner city neighbourhoods to the suburbs. The authors of the Toronto City Report trace the relocation of the main 'ethnic' linguistic neighbourhoods from the downtown to the suburbs. Hence, whilst the city's Chinese community was originally concentrated near Elizabeth and Hagerman Streets, it is now concentrated in the suburbs of Scarborough, Markham and Mississauga. In Toronto, less than 10\% of all areas in which Chinese immigrants are concentrated are downtown; they are for the most part located in the suburbs. An article in the Toronto Star newspaper makes the point that Chinatown, Greektown and Little Italy now resemble tourist landmarks, while new immigrant neighbourhoods grow in suburbs. Another common feature is that these types of distinct urban areas are not exclusively sites for one speech community or ethnicity. According to Agrawal, an expert in ethnic enclaves and urban planning, 'The Greektown is not Greek; Chinatown is not Chinese. They are just ethnic business enclaves where you go, eat, play, have fun and go home' (Keung, 2013).

There are sometimes inconsistencies and contradictions in the language services and language choices provided in city spaces, as we will address in terms of policy in Chapter Four. For instance, the authors of the Athens City Report describe a dearth of street signs in languages other than Greek in most parts of the city, and point out the difficulties that this can cause for visitors. Official street art, sculptures and some attractions are only described in Greek. Aghii Anargyroi, the district investigated during the LUCIDE project, includes the site of Peisistratus's Olive Tree, a natural monument which dates back 2,500 years and represents the ruler's edict to 
farmers to grow olive trees. The significance of this ancient olive tree is only described in Greek; the Athens City Report describes this situation as a missed opportunity. When another language does appear alongside Greek in this district of Athens, it is invariably English.

In Rome, despite significant tourist spending from South and East Asian and Eastern Europe, only European languages feature in the city's self-service rail ticket machines (English, French, German and Spanish). The main tourism website for the city only features the same languages. The website of the Roma Migranda initiative, which provides bespoke walking tours of the city by guides from immigrant backgrounds, is available only in Italian.

\section{[Insert Figure 2.4: Bilingual London recycling sign]}

Multilingual manifestations in urban spaces can emanate from the activities of private citizens as well as the actions of the municipality or public bodies. The London City Report demonstrates some of the pragmatic efforts made by local authorities to communicate in the languages most relevant to local communities, such as the bilingual information sign in Tower Hamlets on the disposal of rubbish in English and Bengali (see Figure 2.4). Somali also appears in some local authority signs and newspapers in this district of London.

In central London, and in the centres of other cities that are major tourist destinations, most visible multilingual manifestations tend to be aimed at visitors rather than locals. The Transport for London website provides content in fifteen languages other than English. Detailed information is provided about transport options, the city's Oyster cards and contactless payment methods, but these are hidden at the very bottom of the homepage under a link to Other Languages. The link is in English, in small font, and near the terms and conditions section of the website. The London LUCIDE team describes the limited effectiveness of some measures. For instance, one respondent describes how, 'In a mainline London station, a notice read: 'If you need an interpreter, go to platform 8'. All the LUCIDE City Reports point to serious lacunae in public transport. In London, despite multilingual welcome signs, the really useful information tends to be provided in English only, both in notices and in announcements. 
In Utrecht, tourists and non-Dutch speaking residents of Utrecht may find it difficult to navigate around the city using public transport, as information is often provided only in Dutch. At Utrecht Central Station for instance, all signs are in Dutch apart from information about international trains or trains to Schiphol Airport. Few public signs in the city give information in any other language but Dutch (apart from the Japanese example cited above). They provide the example of the Dom Church, with its famous Dom Tower. A public sign pointing to it and to other local museums and tourist sites is provided only in Dutch, with the exception of the sign pointing to the Aboriginal Art Museum, which does not have a Dutch name. Residents interviewed by the report's authors pointed to the need for more 'internationalization' of the city. One respondent mentioned that this could be done through "providing more English subtitles throughout the city, for instance on street signs or boards or in restaurants.' Several respondents from Utrecht noted that their municipality's interest in language issues was 'noticeable and refreshing' (page ref), but drew attention to the fact that much of a fascinating blog on multilingualism in the city is provided only in Dutch! To consider these issues in greater depth in the following section, we will now explore three cities surveyed by the LUCIDE network, drawing on the primary and secondary data collected on visible manifestations of multilingualism in Hamburg, Strasbourg and Dublin.

\section{[Insert Figure 2.5: Hamburg food packaging]}

\section{Views from three LUCIDE cityscapes}

\section{Hamburg}

The authors of the Hamburg City Report describe the multilingual landscape of the city, and contrast the use of English in street signage and public transport with the use of heritage languages which tend to be only visible in districts where migrants live or shop. Located near the main railway station, the St Georg district in Hamburg is a district that would be recognisable for many Europeans, a 'hot spot for social, ethnic and linguistic diversity' (Scarvaglieri et al., 2013: 49). Scarvaglieri and other researchers from the University of Neuchâtel, the University of Hamburg and the University of Greifswald studied the languages seen and heard in this part of the city. Overall, the district is characterised by its density, a young population, a high percentage of recent migrants, especially from Turkey, Central and Eastern Europe. 
There are fewer families living in St Georg than elsewhere in the city. The St Georg district divides into two clearly distinct zones: Steindamm and the Lange Reihe. Steindamm is composed of grocery stores, cafés and snack bars mostly selling products from Turkey, Iran, the Middle East and East Asia, as well as being known for prostitution and gambling. Just a few metres away, Lange Reihe is often described as a 'gentrified' part of the district, home to higher-end shops and more expensive restaurants offering Italian and Portuguese food. Lange Reihe is visited both by tourists and locals, and is home to a sizeable gay community. Here, languages such as English, Italian and Spanish are clearly visible.

Whilst German language signage seems to be a predominant feature in St Georg overall, a closer look confirms that about a quarter of the 1034 documented signs in the district do not in fact include any German at all (Scarvaglieri et al., 2013). And although about two-thirds of the signs are monolingual German signs, in line with some 'dominant domestic discourse' (ibid.: 56) that considers Hamburg to be monolingual, the remaining third of the signs are either bilingual or multilingual. The less prosperous Steindamm is more linguistically diverse than Lange Reihe, with twice as many bilingual or multilingual signs. Grocers advertise their produce in Arabic, Turkish or Farsi, and the travel agents, hairdressers and snack stands cater to a clientele who speak a range of languages.

The research team describe a typical Turkish grocery store, Sönmez Markt. Markt is the German word for market, whilst Sönmez means 'never dies' in Turkish. A slogan below the name of the shop is provided uniquely in Turkish which is translated by the researchers into English as 'Our strength comes from quality' (ibid.). The shop front also includes Turkish and English bilingual signage. The crates of fruit and vegetables are described in small individual signs; these are only written in German, as well as the units for prices (Stück, or per item). The research team propose that the different languages used in the signs perform different communication functions. They suggest that "non-domestic languages are typically used to set up an interaction system' - affiliation, attracting passers-by and advertising (just Turkish or Turkish and English). The German language is only used once customers have been attracted into the shop and are browsing the goods, to find out the prices or to see what is at a reduced price - 'for performing linguistic actions which are at the core of an already established action system' (ibid.: 61, original italics). 
The multilingual cityscape of Steindamm is shaped by labour migration to Hamburg, and by the plurilingual repertoires of individuals who use a variety of home languages as well as German to carry out everyday transactions. On the other hand, the multilingualism of Lange Reihe, with displays of international languages such as English, Spanish and Italian, reflects the gentrification of the street and high symbolic value of these languages which perform a decorative function, indexing fashion and luxury products. In a similar vein, one respondent interviewed by the authors of the London City Report (61) described 'pseudo-Italian restaurants' which use Italian simply as a branding technique to entice customers:

You go to a so-called 'Italian' restaurant and the menu is in Italian (more or less) but actually no one there is Italian! So you get the impression you can speak Italian but if you do, it doesn't work!

In the case of the St Georg district in Hamburg, it is clear that the Turkish language continues to play an important role as a marker of belonging, otherwise in the commercial world the shopkeepers simply wouldn't bother. The German language proficiency of shoppers is such that all the names of the fruit, vegetables, sales items and pricing are provided in German, pointing to code-switching between German and Turkish. It is also likely that monolingual German speakers use these shops. The use of German signs provide evidence of Turkish-German bilingualism, and suggest that most shoppers who may self-identify as Turkish speakers and choose to buy their groceries in stores which index the Turkish language are fully proficient in German. The Turkish speech community may be considered as having assimilated linguistically, pointing towards a low vitality for the Turkish language, yet seems to maintain a distinctive collective identity, which is generally an indicator of high language vitality.

\section{Strasbourg}

Strasbourg is a site of intense language contact given its geographical position, its status as a border city where workers cross daily from France to Germany and vice versa, and the presence of many European institutions. In 2010, Bogatto and Hélot conducted the first empirical study of Strasbourg's linguistic landscape. This study focussed on the commercial signs on the shop fronts in the district described as the Quartier Gare, around the railway station: 
As a micro context of cultural, social and linguistic mixing the Quartier Gare lends itself particularly well to an analysis of linguistic diversity and of the possible spatial delimitations, appropriation and construction linked to the production and display of urban written signs. (Bogatto and Hélot, 2010: 6-7)

The features of this part of the city are common to many other European cities: it is quite an old district, with a multi-ethnic population of varied socioeconomic status, and there are many small shops as well as the infrastructure serving the train station. Choosing such a district for analysis provides rich data in the study itself, but also allows for future comparisons with similar districts in other cities. The study focuses on shop fronts as 'instances of individual discourses (ibid.: 7), which point the reader or sign viewer towards expressions of the shop owner's local or global identity. As in other studies of this type, the researchers organise the photographs of the shop fronts according to units of analysis, which may contain several photos of different aspects of the same shop front. In the Quartier Gare in Strasbourg, Bogatto and Hélot collected and analysed 170 'signs' or units of analysis.

\section{[Insert Figure 2.6 Strasbourg restaurant]}

Their findings clearly indicate the dominance of the French language in this district, with $87 \%$ of the signs featuring French. The use of French indexes features of the local area (for instance, Délice de la laiterie refers to the site of a former creamery) as well as choices by shop owners to refer to their global identity through the medium of French (Restaurant Le gourmet d'Afrique, Délices d'Asie, La boutique antillaise, Restaurant Le Cappadoce). These signs point to Africa, Asia, the French Antilles and Turkey.

The Strasbourg City Report describes the use of Alsatian in the city. Whilst Alsatian is highly visible in Strasbourg's street signs, it is not so apparent in the city's commercial signs. For instance, only five of the 170 signs described by Bogatto and Hélot (2010) contained instances of Alsatian on display; four of these referred to restaurants serving Alsatian dishes. The remaining sign on a shop front read: 'We speak Alsatian' (Mir rede Elsassisch). Turning to the visibility of the neighbouring language of German, again a small subset of four signs featured German text. As in the case of Alsatian, three of the four referred to restaurants and were destined for tourists. An analysis of the city's linguistic landscape suggests that not all of the languages of residents are visible in the streetscape. For instance, only Arabic, Thai 
and Mandarin Chinese were recorded as visible around the Quartier Gare, and Bogatto and Hélot (2010) only recorded six instances overall of their use, on restaurant signs, on an Asian supermarket sign, on grocery stores and on a mobile phone shop. They describe how the appearance of these signs, alongside French, provide a decorative function for readers who cannot decode their meaning:

Therefore it is not the content of the message, which is important but rather its presence which brings to mind distant lands and a certain exoticism, all the more since it is always made explicit by meta discursive language, for example: Traiteur chinois, Spécialités thaïlandaises, Téléboutique, Boucherie Traiteur Alimentation, etc. (ibid.: 15).

A noteworthy aspect of this study of the neighbourhood around the railway station is how the use of Turkish family names is featured in signage. Eleven signs contained the Turkish language, and these featured family names rather than messages in Turkish:

[I]t could be one of the specificities of the Quartier Gare since this expression of identity through the display of Turkish names seems to be clearly assumed, whereas in other areas of Strasbourg, it is not rare for Turkish shop owners to hide under less stigmatised identities such as a Greek one for example. (ibid.:16).

\section{Dublin}

Dublin's linguistic landscape reflects the significant population changes in Ireland in recent years. Kallen describes how the linguistic landscape in Dublin was 'very much a two-language affair' (2010: 43) until recently. English was the dominant language in private signage and many public signs, with bilingual signs in Irish and English in 'state-related functions such as street and place-name labelling, traffic regulation and the identification of public buildings of various kinds' (ibid.: 44). Irish is visible in some private signs on shop fronts, although there are fewer of these in Dublin than in other towns and cities in Ireland. In his study of Dublin's changing landscape, Kallen (ibid.) refers to three key phenomena which have resulted in changes in the cityscape: changes in tourism flows, especially in the countries of origin of tourists which are more diverse than previously, growth of international retail and commerce, to which we also add the growth of multinational companies who have set up their headquarters in Dublin, and immigration. His study explores the 
role that inward migration has played in the development of the city's linguistic landscape.

Irish/English bilingualism is initially the most salient feature of the Dublin cityscape. As Carson and Extra (2010: 8) remark, 'Travellers who arrive at Dublin airport from abroad easily receive the impression that they have arrived in a bilingual country.' However, outside of the public (or civic) and educational spheres, Irish is not as visible as public signage suggests. One of the interviewees in the Dublin City Report notes, 'Having lived in Dublin for several years I am surprised by the lack of people that speak Irish. Only on occasion over the past 10 years have I heard Irish language conversations'. Interviewee 1 describes displays of Irish as haphazard, and suggests a different model: 'In Canada, French and English appear on all domestic goods, though perhaps it doesn't help with the usage of language, it helps with the visibility of it.'

\section{[Insert Figure 2.7: Dublin street sign]}

The Irish language has a protected status in the public sphere (including education) due to its constitutional recognition as 'first official language' of the Republic of Ireland (Bunreacht na hÉireann, 1937, Art. 8). The Constitution recognises English as the second official language. Although Ireland's public sphere has operated bilingually in many respects, the Official Languages Act of 2003 seeks to strengthen the provision of Irish in public services. For instance, according to the Act,

oral announcements (whether live or recorded) made by a public body, the headings of stationery used by a public body and the contents and the lay-out of any signage or advertisements placed by it shall, to such extent as may be specified, be in the Irish language or in the English and Irish languages.

Ireland's official language policy is immediately visible in traffic signs: 'The use of Irish on the country's traffic signs is the most visible illustration of the state's policy regarding our official languages, Irish and English. The road authorities are obliged to adhere to the obligations imposed on them with regard to the use of those languages on traffic signs under the Traffic Signs Manual' (An Coimisinéir Teanga, n.d.). A Statutory Instrument in 2008 provided clarity on the presentation of bilingual signage placed by public bodies, which must either be provided in the Irish language, 
or in the Irish and English languages. The following provisions apply to bilingual Irish and English signage (Article 7.2):

(a) the text in the Irish language shall appear first,

(b) the text in the Irish language shall not be less prominent, visible, or legible than the text in the English language,

(c) the lettering of the text in the Irish language shall not be smaller in size than the lettering of the text in the English language,

(d) the text in the Irish language shall communicate the same information as is communicated by the text in the English language, and

(e) a word in the text in the Irish language shall not be abbreviated unless the word in the text in the English language, of which it is the translation, is also abbreviated.

Ireland's legislation explains the visual - although not always grammatically accurate - prominence of the Irish language in Dublin in the civic sphere. As Kallen (2010: 47) notes, '[b]ilingualism here is not dependent on linguistic vitality in the sense of everyday language use'. Whilst Irish is not as visible in the city's economic sphere, what Kallen and Ní Dhonnacha describe as 'Celticised English' (2010: 22) is ubiquitous in Dublin city centre, its symbolism pointing towards Irish authenticity. This often includes the use of English names in a Celtic script rather than lexical items. One well-known online restaurant guide lists 600 restaurants in Dublin city centre, of which only eight have Irish names. Whilst Dublin is geographically distant from the Gaeltacht areas of Ireland (where Irish is formally recognised as the predominant language, mostly located in the west of Ireland), the Irish language is audible in the city. Nevertheless, just how often (and how much, and how well) Irish is spoken in everyday public life is a subject of controversy. Take, for instance, an extract from a tourist information website (www.dublin.info):

The language spoken in Dublin is English. Street signs and official buildings are signposted in both English and Gaelic, the indigenous Irish language. Despite this, you are highly unlikely to hear any Gaelic spoken on your travels across town. You are, however, likely to come across a lot of cursing in casual conversations. Relax, it does not carry the same connotations it might in other languages.

The intersection between the languages most likely to be heard in Dublin is beautifully illustrated in a short film by Daniel O’Hara (2003), entitled Yu Ming is Ainm Dom (My name is Yu Ming). A young Chinese man decides to come to Ireland, having picked his adventure at random by spinning a globe. Before coming, his next 
step is to learn Irish. However, on arrival in Dublin, he is perplexed to discover that no-one understands him. He meets an elderly man, Paddy, in a pub who explains, $N i$ labhraitear Gaeilge anseo, labhraitear Béarla anseo, ó Shasana! (Irish isn't spoken here, English is spoken here, from England!). The eavesdropping barman is amazed at the conversation between the two, and exclaims, 'Did you know that ol' Paddy could speak Chinese?' The young Chinese man happily finds a job in the Connemara Gaeltacht (Irish-speaking area) where he can use his language skills to welcome American tourists. Whilst this Irish language learner is featured as moving to the west of Ireland, significant concentrations of Irish speakers have emerged in Dublin as a result of revitalisation activities. These speakers are in addition to those from the Meath Gaeltacht which was established in the 1930s, just outside Dublin. The recent Gaeltacht Act (2012) allows for recognition to be given which is based on linguistic criteria rather than geographical location. This has led to much speculation that areas with concentrations of Irish speakers (such as the suburbs of Clondalkin or Ballymun in Dublin) may attain some sort of Irish-speaking status (O'Carroll, 2012), and the notion of Urban Gaeilge is now raised in the discussion of Irish language policymaking (McMonagle, 2012).

Together, the visual evidence from the public spaces of Hamburg, Strasbourg and Dublin point to the different circumstances that have brought together each city's inhabitants - both permanent and temporary, as the next chapter will explore - and illustrate the dynamic of multilingual communication within and between the various speech communities present. In the next section, we address some salient common features which emerged from our comparison of different linguistic landscapes in the LUCIDE cities: the role of English, monolingual signs in multilingual cities, and languages on the edges of city life, in graffiti and informal notices.

\section{Some visible features of multilingual cityscapes}

\section{English language usage}

When it comes to understanding the significance of multilingual signs, unpicking what is informational and what is symbolic can helpful. Hult (2009), in his research on multilingual signs of two areas in the Swedish city of Malmö, distinguished between symbolic and instrumental language use. For instance, in a shop sign in both English and Swedish, the use of English gives no information about 
what a shop sells, only serving to index globalization. The Swedish language sign fulfils the communicative function of telling visitors that it is a food store. English in such instances indexes globalisation, pointing towards modernity, prosperity, youthfulness and so forth in order to sell goods. The English language is visible in all the cities in the LUCIDE network, and its use in commercial signs and advertising, on storefronts and in other aspects of a city's linguistic landscape is ubiquitous. The nature and extent of English language use in Europe's cities have been the subject of several empirical studies. Data from these studies suggest that English plays a variety of roles according to sphere. For instance, Ball (1989) suggests that in France, English language tokens tend to feature in luxury or entertainment establishments such as travel agents and florists, cafés and night clubs, rather than in shops which provide the everyday necessities (bakers, butchers, hardware stores). A study by Schlick (2003) explored the use of English in clothes stores in Austria, Italy, and Slovenia. In an investigation of English shop signs in Macedonia, Dimova (2007) notes that the 'extent of English present in shop signs varies among cities depending on their size and their roles in commerce, diplomacy, foreign trade, and tourism'.

Part of a city's linguistic landscape is of course derived from the brand names and slogans of multinational companies. In addition to these, many of the English or 'English-ised' names have been created locally, for regional or national changes, or for individual establishments. It can be argued that these signs are not simply deployed to attract customers who can read them in English, but that they are also on display for the whole population, indexing prosperity, luxury, prestige and so forth. In the St Georg district in Hamburg mentioned earlier in this chapter, English is the most frequently deployed language in signage apart from German: $30.6 \%$ of the signs recorded in Steindamm contained English (Scarvaglieri et al., 2013). The English language features in $15 \%$ of the signs analysed by Bogatto and Hélot in the Quarter Gare in Strasbourg; three of these were monolingual signs, uniquely in English. Their study explores the connotative aspects of English language use in these signs in Strasbourg, indexing modernity, cosmopolitanism and fun, in clothes shops, restaurants and bars, and mobile phone and photocopying shops. The findings here confirm Ball's (1989) suggestion that in France, English language tokens tend to feature in luxury or entertainment establishments such as travel agents and florists, cafés and night clubs, rather than in shops which provide the everyday necessities (bakers, butchers, hardware stores). 


\section{[Insert Figure 2.8: Hamburg coffee shop]}

The authors of the Osijek City Report pinpoint two parallel trends in the city's linguistic landscape: the appearance of English in the names of pubs and shops and in graffiti, and the trend of 'keeping history' (45) through using the names of famous figures from the past, particularly German and Hungarian names. The ubiquity of English is particularly evident in the hospitality industry in Osijek. The City Report provide examples of how English is used in the names of cafés and bars. The researchers surveyed a directory of establishments; those which offer wifi to customers are listed below:

- Brooklyn

- Caffeteria Exclusive

- Cat

- Goldfinger

- Golden Sun Casino

- Lounge Bar Nox

- Matrix Caffe

- New York

- News

- Old Bridge Pub

- Saloon

- San Francisco Caffe Bar

- Sporting Caffe Bar

- St Patrick's Pub.

All of these names are based on place names from the English-speaking world or use English language markers. Many of the signs are unilingual. Croatian is not deployed as a marker. As in Dimova's analysis (2007) of shop signs in Macedonia, these names demonstrate a distinct orthographical feature. Although most English words in these names maintain their original and correct English spelling, the word café is written as caffe (or caffeteria) in almost all signs. Whilst the English language is used in the names of cafes and bars, the city also demonstrates an essekersich tradition where establishments display German names in memory of famous citizens, for instance the Waldinger hotel (a famous painter from the city), the Guesthouse Maksimilian (a café named after a renowned $19^{\text {th }}$ century Bürger), and the Beckers café (marking the commander of the Osijek fort, General von Beckers). Streets are also named after famous German or Hungarian residents. One of the residents interviewed for the Osijek City Report describes how Hungarian is only audible in the 
marketplace, and went on to point out, 'globally, it is all about English [...] the names of the shops, bars'.

Some cities in the LUCIDE network are subject to legislation which impacts on the languages used in advertising and storefronts. In Montreal, commercial signs are subject to the Charter of the French Language, or Bill 101. In its original form, this legislation required signs to be in French only. Following amendments to the Charter, some resulting from litigation, it now requires in the case of bilingual signs, that the French part of the sign must be predominant. Bouchard (2008) reported that French was clearly predominant in $85.2 \%$ of the business surveyed, not predominant in $7.4 \%$ and absent in $7.4 \%$. Only a small percentage (6\%) advertises in a language other than French or English. In Strasbourg, the city's public services and commercial operators are subject to the Toubon Law of 1994:

The use of French shall be mandatory for the designation, offer, presentation, instructions for use, and description of the scope and conditions of a warranty of goods, products and services, as well as bills and receipts. The same provisions apply to any written, spoken, radio and television advertisement.

In the streets of Strasbourg, as elsewhere in France, this has resulted in continued use of English and other languages in advertising, which are marked with an asterisk. The French translation appears in a miniscule font at the bottom of the billboard or sign. In Varna, municipal regulations on advertising in the territory of Varna, published in 2009, stipulate that all texts in public outdoor advertising, on noticeboards and in public notices should be written in Bulgarian, and should only use foreign trademarks or brands if they are associated with companies which trade internationally. Shop signs demonstrate heterogeneity, with a combination of unilingual Bulgarian signs, combinations of English and Bulgarian, and the use of foreign words transliterated into Bulgarian. Whilst establishments aimed at younger customers tend to use unilingual English signage, many small businesses in the city continue to use the Bulgarian language in an exclusive manner, although sometimes two separate shop signs are provided, one in Bulgarian and another in English or another language.

\section{Monolingual Signs}

Sometimes monolingual signs target a specific language community for specific purposes, indexing specific social situations, or are used where a bilingual or 
multilingual sign would have been more useful — perhaps pointing to a lack of funds, lack of will or lack of knowledge on the part of the provider. In Dublin, a temporary sign appeared beside the sauna at a public swimming pool in the city centre. The information contained in the sign was not provided in English or in any other language, and it seemed to be specifically targeting the behaviour of Russianspeaking users of the sauna. In English, the translation reads, 'Attention! It is strictly forbidden to bring or consume alcoholic beverages and also to be under the influence of drink. Offenders will be punished' (personal communication with Sarah Smyth). We can make several inferences from this sign. Firstly, that there have been sufficient 'offenders' bringing alcoholic drinks with them to merit this sign, that these individuals have been Russian-speakers, and that the management of the pool do not deem other groups to be in need of a similar warning (e.g. Polish speakers or Mandarin speakers). The full import of the sign requires deeper cultural knowledge: for visitors from a Russian background, the Russian style of using a sauna or banya (баня) will almost inevitably involve drinking vodka or cold beer (or tea) during cooling periods before re-entering the sauna. However, in Ireland, alcohol is banned throughout the country in all swimming pools and spas, steam rooms and saunas.

In 2012, many residential buildings in neighbourhood of Kanaleniland in Utrecht were evacuated due to large-scale exposure to asbestos caused by renovations by housing corporations. More than three-quarters of residents in the district are not ethnically Dutch, and there are large communities of Moroccans and Turks in particular. The evacuations occurred rapidly and streets surrounding the apartment buildings were barricaded by the police whilst investigations were carried out by inspectors. Warnings and announcements about this emergency situation were provided only in Dutch, including street signs about extensive road closures.

\section{[Insert Figure 2.9: Utrecht information sign]}

\section{Languages on the edges}

Liminal spaces — the 'in-between spaces' of cities - are often sites of particular interest in the study of a linguistic landscape. Scollon and Scollon (2003) identify 'transgressive discourses' in urban space as one of types of dialogue which occur between those who place signs and those who view them. Transgressive 
discourses refer to signs that are not presented in a conventional manner, or 'meaning out of place' (Scollon and Scollon, 2003: 161). The most typical example of transgressive discourse is graffiti. Another interesting aspect of the liminal landscape is that which only exists temporarily: posters, private notices and so forth. Kallen draws our attention to the detritus zone, the accumulation of waste with languages printed on them, such as a cigarette packet, a discarded ticket or an abandoned leaflet. According to Kallen $(2009,2010)$, those random and scattered wastes are indexical of population movements and the trace of their presence in Ireland. In his work, Kallen suggests that the detritus zone deserves due attention, playing its own particular role in the cityscape.

\section{[Insert Figures 2.10: Oslo graffiti]}

In the LUCIDE cities, the Athens research team report a predominance of English in graffiti and street art in the city, sometimes alongside Greek but often only in English. The city of Varna also provides examples of graffiti in English. The Latin alphabet, rather than the Cyrillic alphabet, and the English language dominate graffiti in this Bulgarian seaside resort. Varna regularly hosts graffiti and street art events, and the Varna City Report tell us that local artists have recently been promoting the use of Cyrillic alongside English. In Croatia, Osijek has also been host to graffiti competitions, and in this small city, much of the graffiti is, like in Athens and Varna, in English. In Oslo, there is predominance of graffiti in English. Much of the graffiti in the city demonstrates influences from the USA and the UK, including music (heavy metal groups, hip hop) and political statements.

Public noticeboards are also located in a city's liminal space, representing an ever-shifting dialogue between the private sphere and the civic or urban sphere. These types of bulletin boards include advertisements for services and events posted by individuals or associations, and reflect the languages spoken in a district. The noticeboard in Figure 2.11 below is particularly interesting, with three adjacent yet distinct signs. From the left side, the first side is bilingual, in Norwegian and in Arabic. Posted during Ramadan in Oslo, it explains opportunities to donate according to the practices of fidya and kaffara. At the bottom of the sign, a slogan in English identifies the 'Helping the Needy' charity. The next sign is notice of a forthcoming protest at the Pakistani Embassy in Oslo, following the violence of the 'Model Town massacre' in the Punjab. The sign is predominantly monolingual, although the slogan 
'state terrorism' appears in English. The third sign, a notice from the Ghousia Muslim Society, is almost exclusively in Arabic. At the bottom of the noticeboard, a poster for the Oslo Extra Large publicity campaign (OXLO) is visible. Another noticeboard from the Oslo Public Library (see Figure 2.12 below) advertises language courses in Italian and in Japanese in Norwegian with some display aspects of Italian and Japanese. English is used alongside Norwegian to advertise theatre and concerts (Still in Silence, Desert Blues, The Crimson ProjeCKt, Mad Fingers Ball, The Golden Voice of Mali).

\section{[Insert Figures 2.11 and 2.12 : Oslo billboard and noticeboard]}

\section{The sounds of the cityscape}

You go out in the streets and you hear so many languages, on an everyday basis so it's more and more accepted, and the world is getting smaller because of movies and the internet and everything, so it's more and more accepted. And for our generation, but still, our generation thinks this but those who decide now are actually our parent's generation. So I hope it will be better but I don't think because of the political programme, but because this is how the world is going. The world is getting smaller and we talk to each other on more spaces than we did before, social websites and everything so it's more natural to hear - in the music, in the movies, and everything. (Oslo City Report: 58)

Whilst the study of written discourse in the linguistic landscape can be illuminating, the voices of speakers are an important aspect of understanding the vitality of a multilingual cityscape. In this last part of the chapter, we turn to some of the sounds and voices that we hear in European cities, in the public and private spheres of television and radio broadcasting, and in the new varieties and practices that seem to be emerging as a result of close language contact.

We can apply the same questions to the concept of audibility as to the concept of visibility: why are certain languages audible, what is their impact on listeners, who chooses the languages which feature in announcements or in broadcasting, and why? Scarvaglieri et al. (2013: 63) build on such questions, and assert that 'the linguistic soundscape offers insights into language use trends within a given society'. They report on their 'soundwalks' in the St Georg district, which involved ethnographic observations and recordings of public utterances and conversations in bars, shops and restaurants where interlocutors gave their permission to be recorded. Whilst the majority of conversations in both Steindamm and Lange Reihe were in German, the 
proportion was much higher in the gentrified Lange Reihe area (83\% German) than in Steindamm (39\% German). Apart from German, in Steindamm the two largest language groups were Turkic languages (17\%) and Arabic languages (8\%). In Lange Reihe, 3\% of conversations featured Turkic languages, and 2\% featured Arabic languages.

Cronin (2004: 9) cites a Romanian journalist's experiences of Dublin's transforming soundscape in 2001. Anna Lebedeva writes, 'Walking around Dublin these days is like travelling the world. The streets echo the languages of the city's newly found diversity and one cannot stroll the span of the Ha'penny Bridge without bumping into a foreigner.' But the Dublin City Report illustrates how linguistic misunderstanding can lead to tense situations. One interviewee describes a communication breakdown witnessed on public transport in Dublin due to a passenger's lack of proficiency in English:

Every country in the world is represented [on my bus] and you see a lot of racial clashes. The last time was last week [...] the card wasn't working and there was quite a tense exchange between her and the bus driver. She didn't quite have the English to - she just kept saying, 'It not work, it not work,' and he was going, 'Show it to me, it's out of date' and there was a whole issue.'

The same interviewee, a native-speaker of Irish, describes how the Irish language itself may not be recognised by hearers in Dublin, despite the fact that Irish is a compulsory component of formal schooling throughout the primary and secondary cycles. In the primary cycle, four hours in the curriculum each week are dedicated to Irish as a Second Language. Yet, as this interviewee describes, many Irish people are unable to identify the Irish language when spoken by native speakers:

I think we're not terribly attuned to language generally, and on a personal basis I'm probably asked three times a week what language I'm speaking when I'm speaking Irish by Irish people [...] People occasionally get a bit shy around me [when I'm speaking Irish] or a bit defensive. When people ask me what language I'm speaking, the response is 'Well I always hated [Irish] in school, I can't stand it'. It always initiates a strong emotional response, whether it's positive or negative.

\section{Television and radio broadcasting}

Public service and independent broadcasting are an important part of the multilingual landscape in the city, despite the growth in news and entertainment 
Carson, Lorna (2016). The Sights and Sounds of the Multilingual City. In King, Lid \& Lorna Carson (Eds.) (2016). The Multilingual City: Vitality, Conflict and Change. Bristol: Multilingual Matters, pp. 49-86.

accessed via the internet. The LUCIDE City Reports demonstrate some of the diversity of broadcasting, the extent of support for local language needs and visibility of language varieties.

Some of the LUCIDE City Reports mention the provision of signed language programmes. Television broadcasting can offer a vital source of information and entertainment for Deaf viewers. The use of signed languages in the television sector varies across the cities surveyed in the project. In Athens, the Greek national television broadcasts a summary of the daily news each evening in Greek Sign Language. In Sofia, the Bulgarian national television service provides a daily news broadcast in Bulgarian Sign Language. The status of Bulgarian Sign Language was bolstered by the establishment, by the Union of the Deaf in Bulgaria, of a National Centre for Sign Language in 2004. Whilst Irish Sign Language lacks legal recognition in Ireland, the national public service broadcaster RTE (radio telefis eireann) has been engaging recently with the Irish Deaf community to extend programming in Irish Sign Language (ISL), including during primetime slots. Currently, three and half hours of programmes are broadcast each week in ISL in addition to the daily news and weather.

Radio has long been a lifeline for migrant communities, and community radio plays a particularly important and cost-effective role in the visibility and maintenance of languages. Community radio stations are generally independent, not-for-profit initiatives. Raidió na Life is an independent radio station based in Dublin (the name of the city's river Liffey is derived from its name in Irish, An Life) which provides a platform Irish language organisations, Irish speakers, people with an interest in the language and music-lovers of all kinds - including those who would not necessarily have regular contact with the Irish language. The station takes care to include a wide range of interests in its programmes, with a focus on Dublin city and county as well as the commuter belt. It is a multicultural and diverse community, vis-a-vis the range of interests, age profile, level of fluency in Irish and active participation in the Irish language community.

London's Resonance FM 104 provides some output in Farsi, Serbian and Albanian; the Voice of Africa Community Radio broadcasts in English and African languages with some French and Portuguese output. In Melbourne, 64 community groups work with the city's community radio station (3ZZZ), and some 400 volunteers broadcast in 57 languages each week. Rome has a similarly vibrant 
community radio sector. For instance, many of the community stations feature programmes for the city's Filipino population. The Filipino population in Rome tends to work in the healthcare and domestic service sector, as carers, housekeepers and nannies, gardeners and drivers. As well as featuring news and music from the Philippines, the programmes address aspects of living as an immigrant in Rome, including visa issues and migrant rights.

- Buhay Pinoy (Pinoy Life, on Radio Spazio Aperto)

- Kaibigang Pinoy Radio (Pinoy Friends Radio) and Radio Pinoy Balitang Bayan (Pinoy News Round Town, both on Radio Roma $103.95 \mathrm{fm}$ )

- Radio Sentro Pilipino Ng Vaticano (Vatican Radio Association, on Radio Vaticana 1611 am)

- Ugnayan sa Himpapawid (Contact the Air, on Radio Città Aperta 88.9 FM), celebrated its 15th anniversary in 2014

- Bato-bato sa Langit (Radio Onda Rossa, 87.9 FM), established in 2004

There are over 2000 community radio stations across Europe, and can be heard in most of Europe's cities (Buckley, 2010). A European Parliament Resolution in 2008 noted that community media are 'an effective means of strengthening cultural and linguistic diversity, social inclusion and local identity'. The Resolution describes how community media 'promote intercultural dialogue by educating the general public, combating negative stereotypes and correcting the ideas put forward by the mass media regarding communities within society threatened with exclusion, such as refugees, migrants, Roma and other ethnic and religious minorities', and stresses that 'community media are one of the existing means of facilitating the integration of immigrants and also enabling disadvantaged members of society to become active participants by engaging in debates that are important to them'.

\section{Multiethnolects}

A fascinating and relatively recent phenomenon resulting from the interplay of languages and culture in contexts of migration, language contact and second language learning has been the emergence of new kinds of urban communication - the multiethnolect. There are examples of this in increasing numbers of cities, including the LUCIDE cities, most notably Utrecht and London. This too is becoming part of the multilingual city's soundscape. The convergence of people inevitably involves regular language contact which impacts on linguistic practices. For instance, in their study of Hamburg's soundscape, Scarvaglieri et al. (2013: 68) describe how a variety 
of languages are deployed on the streets and inside the grocery stores of the Steindamm area in St Georg:

[...] the employees behind the counter chatted amongst themselves in Arabic, with their customers waiting in line and conversing in small groups. One group of customers was speaking in Ewe, another group in English, a third group in Kurdish. Still, when issuing an order and thereby communicatively transcending the borders of their own language group, each of the groups regularly switched to German. The German used in these cases at times had a non-native soundscape, in other cases it could be recognized as native German; no matter how the German sounds, however, ethnographic observation allows us to identify German as the intergroup-language, facilitating communication amongst people from different and diverse language groups.

One of the respondents interviewed by the Hamburg team refers to the emergence of German-Turkish, a variety of Turkish that is influenced by German syntactical and lexical features, particularly the use of the definite article. This example and other data suggest that language practices in Europe's cities are audibly changing and that new urban varieties or styles of speech are emerging, especially amongst young people and in sites of high density housing with an elevated percentage of second language learners from diverse origins.

In the Netherlands, Dorleijn and Nortier (2012: 480) have explored the 'very specific slang-like linguistic varieties [that] pop up among urban, multi-ethnic adolescent groups', variously described as youth slang or youth language, or the language of the street. In Germany, it has been described as Kiezdeutsch (Wiese, 2006), and in Sweden as rinkebysvenska (Kotsinas, 1988). Cheshire et al. (2011) coined the term Multicultural London English for the variety that is apparent in London. Dorleijn and Nortier point out that despite different locations (in Utrecht, Hamburg or London for example), these emerging varieties share similar features and characteristics. They provide the following definition (2012: 481) of a multiethnolect, a term coined by Clyne in 2000 , as:

a linguistic style and/or variety that is part of linguistic practices of speakers of more than two different ethnic and (by consequence) linguistic backgrounds, and contains features from more than one language, but has one clear baselanguage, generally the dominant language of the society where the multiethnolect is in use. 
Whilst Nortier and Dorleijn stress this is not a new linguistic phenomenon, citing work on African urban youth languages, on African American Vernacular English and amongst Puerto Rican-American groups, it is clear that European multiethnolects are found in cities amongst among adolescents with a migrant background, 'involved in the process of constructing and presenting a social identity, [...] an unavoidable consequence of living in the highly dynamic circumstances [of] multiethnic neighbourhoods in large urban areas' (Nortier and Dorleijn, 2013: 233). Cheshire et al. (ibid.: 190) trace the beginnings of Multicultural London English from the 1980s onwards, and describe the social conditions as 'the presence of an exceptionally high proportion of speakers of language varieties other than the local variety, here, London English - 50 percent or higher in parts of some boroughs, sustained over a considerable time by continued immigration'.

Cheshire et al. (ibid.: 153) explore how the addition of the host language to children's repertoires influences the development of a multiethnolect:

People of different language backgrounds have settled in already quite underprivileged neighbourhoods, and economic deprivation has led to the maintenance of close kin and neighbourhood ties. [...] In these communities, there is often a rapid shift to the majority language by the children of the migrants, possibly accelerated by the fact that there are a large number of languages spoken in areas without strong residential segregation. Because majority-language speakers may be in a minority in parts of these districts, the availability of local, native models of the majority language is weaker than elsewhere. This means that the majority language may be acquired from other second-language speakers.

The presence of speakers of other varieties creates covert prestige features. Nortier and Dorleijn (2008) refer to occurrences of Dutch pronounced with a Moroccan accent in Utrecht, even by speakers who are not of Moroccan origin. Such vernacular speech styles, deployed for intra-group communication, tend to include regular code-mixing as well as distinctive phonological, morphosyntactic and lexical features. These include 'exaggerated and consciously stereotyped features characteristic of second language learners (grammatical structures, pronunciation, prosodic features)' and 'insertions of (non-dominant-language-) formulaic expressions, greetings, discourse particles, all kinds of interjections, (taboo) content words and even occasionally function words of diverse linguistic sources', as well as word revision in some multiethnolects. The following example, taken from Nortier 
and Dorleijn (2008), sheds light on a lexical feature as well as the speaker's awareness of the choices made according to interlocutor and context:

R: $\quad$ Dat is het slechte Nederlands

I: $\quad$ En heeft dat ook een naam?

$R: \quad J a$, niet echt, maar 't is in principe dan eh lidwoorden die gebruikje dan expres verkeerd.

I: $\quad J a$, ja, die gebruik je dan exprès verkeerd, net als-

R: $\quad J a d u s$

I: $\quad$ Die meisje

R: $\quad$ Die huis zeg ik dan. Terwijl ik weet ik bedoel ik weet heus wel dat het dat huis is, maar 't staat zo dom als ik dat op straat zeg, als ik zeg

I: $\quad J a$

R: $\quad$ Als ik zeg dat huis

I: $\quad$ Jaja

R: $\quad$ 't Is gewoon die huis. Maar als ik met jullie spreek dan wordt 't gewoon dat huis.

R: $\quad$ That is the bad kind of Dutch

I: $\quad$ Does it have a name?

R: $\quad$ No, not really, but in principle you uhmm... just use the articles deliberately in the wrong way.

I: $\quad$ Right! So you use them in the wrong way deliberately? Just like-

R: $\quad$-Yes, like

I: $\quad$ Die meisje ('that girl' - dat meisje in standard Dutch).

R: I would say: Die huis ('that house'- dat huis in standard Dutch). At the same time I know, I mean, I am very well aware of the fact that it should actually be het huis, but it would make a stupid impression if I would say...

I: $\quad$ Yes

R: $\quad$ If I would say dat huis out on the street

I: $\quad$ Yes, yes

R: $\quad$ It is just die huis. But when I speak with you (the authors - both Dutch and middle-aged) it is just dat huis.

Interviewees in the Utrecht City Report refer to this multiethnolect as Straattaal, (street language) 'this strange Dutch/Moroccan street language' or 'a nice mix of Dutch, Moroccan, Antillean and Surinamese words and expressions'. One respondent describes how his teenage children help him to understand it.

Cheshire et al. (2011) describe the emergence of Multicultural London English in terms of its phonological and morphosyntactic features as well as the use of a new expression introducing quoted speech, this + speaker. Other quotatives such as here's me + speaker and I was like + speaker are also deployed, as well as use of was in the second person past tense (you was), non-standard negatives (I weren't). 
Unlike Cockney English, there is no h-dropping. The quotative this is + speaker is illustrated by Cheshire et al. in the following examples (ibid.: 172):

1. this is them 'what area are you from. what part?' this is me 'I'm from Hackney'

2. this is her 'that was my sister'

3. this is him 'don't lie. if I search you and if I find one I'll kick your arse'

4. $\quad$ this is my mum 'what are you doing? I was in the queue before you'

5. this is my mum's boyfriend 'put that in your pocket now'

The intensity of the social and linguistic contact in many parts of our cities does not always create an easy context for hearers. In the Netherlands, the type of multiethnolect used by young people is described by themselves as 'the bad kind of Dutch'. Multicultural London English has been described - and rebutted - in the media as threatening, connecting speakers to gang culture and terrorism (Hill, 2013). The audible mix of languages may not be seen as a benefit to the city but rather as a threat. As one interviewee in Oslo described succinctly, the attitude of many citizens to the city's new linguistic diversity is 'By all means, talk Somali, just not so I can hear it.' In Limassol, one of the respondents interviewed by the authors of the City Report describes how some citizens complain about 'foreigners who are 'destroying' the city's civilization [...] and contribute to the loss of the city's identity; everywhere you go, people speak another language'.

On the other hand, many of respondents in the LUCIDE cities saw multilingualism as a badge of honour, a sign of the creativity and spirit of their city. In some cities, a functional bilingualism is part of daily life for many cities. In Oslo for example, English occupies a particular place in most citizens' repertoires. The regular and extensive use of English was described by one of the Oslo respondents as being 'bilingual in the way that all Norwegians are bilingual in Norwegian and English'. In Montreal, one of the respondents distinguishes between the roles that English and French play in the repertoires of its citizens:

Montréal est une métropole importante. Nous travaillons très fort à la positionner sur l'échelle mondiale. S'ouvrir sur le monde, c'est un acte de partage. Parler anglais, c'est se donner une chance de pouvoir s'ouvrir au monde. Parler le français c'est respecter nos valeurs et nos différences.

Montreal is a major metropolis metropolis. We work very hard to place it on the world stage. Opening up to the world is an act of sharing. Speaking 
English gives us the opportunity to open up to the world. Speaking French is a way of respecting our values and our differences.

A respondent from Hamburg, who speaks German, Turkish and English, sees the advantages in a multilingual citizen community:

I realize that when people are multilingual they are more open, this is very pleasant. Also they are more able to see things from a different perspective and don't stay in their cultural networks [...] Especially concerning the resolution of conflicts, multilingual people are better able to compromise and bring the opposing parties together, they find arguments for both sides.

\section{Ordinary multilingualism}

Of course, theory and praxis always clash. I notice that people talk very slow to me because of my Turkish accent. When I am talking Turkish on the phone, people in the subways tell me to lower my voice. When I talk in German nobody says anything. (Stakeholder interviewed by the Hamburg research team)

The park bench I describe at the beginning of this chapter points to a changed situation in the city of Dublin. A landscape that was previously coastal is now a semiindustrial zone; the original view has been irrevocably changed. In many ways, most European cityscapes have undergone the same transformation of their linguistic landscapes. New views include frequent English language signage in public transport or road signs, in shops and restaurants as well as other non-indigenous languages used to sell products and demonstrate affiliations. New varieties of languages are emerging through language contact. In the same way that the park bench is an example of indexicality, pointing us towards an interesting state of affairs, the visibility and audibility of the many languages present in any particular city directs us towards inherent and specific power relations, symbolism and choices.

In the cities described in this chapter, where speakers of many languages live and work in close proximity, the everyday contact and interchange between language speakers must be at the heart of how a city manages its resources, maintains its neighbourhoods and sells itself to the rest of the world. There are large population flows of tourists, international students and temporary workers. For many of these people, English is a lingua franca and a language in through which some services may be delivered. As well as citizens who speak the officially recognised language(s) of 
the city, there are citizens whose languages exclude them from full access to services. As Lamoureux and Clément (2012: 2) ask, should cities reflect the languages spoken by its citizens and residents, or should these citizens and residents adapt to how their city structures and manages language resources? One of the interviews from Strasbourg neatly sums up the challenge:

I think the co-existence of multiple languages in a city is a real challenge for the local government in the sense that they need to take into account the people in their day-to-day life. You cannot ignore these people.

A respondent from Montreal considers who should take responsibility for the provision of multilingual services, a theme we address in Chapter Four:

[...] je ne crois pas que l'administration publique doive assumer tout le fardeau de cette situation. A mon avis, un minimum d'information peut être offert au public, dans différentes langues, mais il faut responsabiliser les citoyens pour qu'ils trouvent eux mêmes un interlocuteur qui puisse faire le lien avec l'administration, en français ou si requis, en anglais.

I don't think that the public administration should have to bear all the burden of this situation. In my opinion, some minimal information should be provided for the general public, in different languages, but citizens should also take responsibility themselves in order to find someone who could help them connect with the administration, in French, or if necessary, in English.

The data from the study of a city's landscape often say less about the demolinguistic composition of its inhabitants than about the prestige of some languages or the influence of language policies. This is particularly the case when we consider the prominence of the English language in all of the LUCIDE cities. The English language has a particular status in Europe and internationally due to its role as a lingua franca and world language, or, as Coluzzi describes it (2012: 239) as a language super partes. Sometimes English is bounded by legislation (as in Dublin, Strasbourg and, to a lesser extent, Varna); elsewhere it is a neutral resource upon which attributes of globalisation or internationalisation can be hung without threat to local or national identity (as in Osijek, Utrecht and Madrid). In many cases, it is used for display and decorative purposes, perhaps not even partially intelligible to all local residents but sending out messages about prosperity and creativity. In Dublin, the role of Irish - first official language yet used rarely for daily communication by most residents in the city - is protected by the Irish Language Act in the public sphere, yet 
it is almost invisible in the economic sphere, including in Dublin's busy hospitality industry. In Strasbourg, Alsatian is visible in official street signs, yet is rarely used in the city's restaurants and shops. In Osijek, the Hungarian language is identified by interviewees as the one language in particular need of a 'visibility boost' in the city, despite a language education policy which provides for schooling through Hungarian (see Chapter Five). Hungarian and Serbian are rarely heard in the city outside of the marketplace and the Reflata district, and the authors of the Osijek report describe minority language use as 'a hidden practice'. Similarly, whilst many Sámi live in Oslo, the language almost invisible in the city's linguistic landscape, and national legislation means that administrative services cannot be conducted through Sámi in the city. In sum, even within contexts where regional and minority languages are supported by legislation, these varieties occupy a rather marginal place in the visual landscape of cities.

Whilst the languages of immigrants in cities are very distinctive in some spheres of city life and in neighbourhoods with high percentages of citizens from nonindigenous backgrounds, not all of the languages spoken in a city appear in the city's visual landscape in the public sphere. Romani, for instance, remains an invisible language in most of the LUCIDE cities despite its vitality in Roma speech communities. A parent in Hamburg described how,

If you speak Turkish in a bus or train people look at you strangely. It's not a curious look but rather a downgrading look, a different look than when you speak English or French. My daughter was asked why she spoke Turkish.

The words of another respondent from Hamburg, again a German/Turkish bilingual, are poignant, pointing to the hidden languages of some citizens:

My parents are from Bosnia. It was sad for me that they never spoke Bosnian to us. When I ask them now they say everyone in our environment spoke Turkish and we wanted to make sure that you speak a flawless Turkish as well. They thought that learning two languages simultaneously would deteriorate the mother tongue. Bosnian was a secret language for them. My mother also didn't speak to my children in Bosnian even though we urged her to do so but she said that they don't react on it, she didn't have the patience. Later she saw many Kurdish families speaking Kurdish in our neighbourhood, this was the first time she realized that she should have spoken Bosnian to us. 
It is important to ask whether the symbolic use of migrant languages observed in many cities (for instance in welcome signs or in an information leaflet) would have helped in these particular case? Would it have reassured the mother that Bosnian was a language worth maintaining? The LUCIDE City Reports suggest that these types of signals - whilst perhaps tokenistic in some cases (e.g. greetings in multiple languages at entrances to buildings) - are a step in the right direction towards the more visible and sustained use of many languages in multiple spheres of city life. Research by Cenoz and Gorter (2006) confirms that the appearance of minority languages in the linguistic landscape does raise language status and bolster maintenance. In other words, even small and symbolic instances contribute to enhanced language vitality, and send out positive signals to local residents that their languages are worthy to be used, to be maintained and to be learned. The authors of the London City Report suggest that once the language of a speech community attains a critical mass, it starts to be reflected in the physical surroundings of the neighbourhood. Other varieties, with smaller numbers of speakers, remain less visible. When the languages of local communities are embedded in the fabric of an area, this can both create a sense of ownership and belonging as well as reflect a degree of valorisation on the part of the whole community (London City Report).

In her ethnography of a multi-ethnic street in London, Hall (2012: 108) writes of 'ordinary cosmopolitanism', a living amongst and recognition of difference without a convergence to sameness'. The streets of our cities have changed irrevocably over the previous century, with the blurring of physical boundaries and distance, unprecedented global mobility of goods and people, and the development of unimaginable technological and communication tools. As we close this chapter and turn to questions of place and belonging, perhaps we can ask whether Hall's definition could equally apply to ordinary multilingualism - an accepted intermingling of different language varieties (regional, minority, indigenous, nonindigenous, prestigious, non-prestigious) in both private and public settings, where we do not fear languages we do not understand, but instead seek to distinguish between them. In the words of a respondent from Hamburg, 'The invisible borders are easier to overcome, to accept the new, the different because in some way it's part of oneself.' The next chapter will explore the images and representations of cities, and what connects citizens - or otherwise - to their multilingual city. 